\title{
\11 МЕЖАУНАРОАНАЯ ПОАИТИКА
}

Хань X.

\section{РОАЬ РОССИИ В ОБЕСПЕЧЕНИИ ЭНЕРГЕТИЧЕСКОЙ БЕЗОПАСНОСТИ ЕВРОПЫ В ГЕОПОАИТИЧЕСКОМ КОНТЕКСТЕ}

\begin{abstract}
Аннотация. Предметом данного исследования является обеспечение энергетической безопасности Европы. Объектом исследования является энергетическая политика России и ЕС. Автор подробно рассматривает роль России в обеспечении энергетической безопасности Европы и транзитных стран в обеспечении европейской энергетической безопасности. Особенное внимание в статье удеıяется анализу роли России в обеспечении энергетической безопасности Европы в условиях кризиса на Украине и его последствий в отношениях между РФ и ЕС в сфере энергетики. Рассматривается роль третьихгосударств в поставках энергоресурсов в ЕС. Методология данной работы включает в себя системный, структурно-функциональный подходы, методы сравнительно-исторического, сравнительно-политического анализа. Автор приходит к выводу, что стратегическое партнерство между РФ и ЕС в энергетической сфере основывается на энергетической безопасности в долгосрочной перспективе. Кризис на Украине ставит Россию перед рядом вызовов, как в геополитическом и геоэкономическом плане, так и в сфере внешней энергетической политики. Без сомнения, Россия в новых условиях не только будет оставаться ведущим оператором энергетического мирового рынка, но и примет активное участие в дальнейшем развитии рынков, значительно усилит свои позиции в глобализации энергетики.
\end{abstract}

Ключевые слова: Россия и ЕС, глобализация, геополитика, энергетическая политика, кризис на Украине, энергетическал безопасность, транзитные страны, страны СНГ, Южный поток, энергетический рынок.

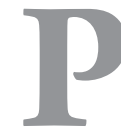
оссия явцяется важной частью мирового энергетического рынка и вхоАит в число крупнейших экспортеров энергоресурсов в мире, особенно в Европе. Энергетическая геополитическая стратегия
России направлена на реализацию следующих целей: обеспечение прямого доступа к потребителям энергоресурсов на территории евразийского материка и созАание общего энергетического консорциума с Аругими 
энергетическими добывающими Аержавами Евразии ${ }^{[2]}$.

В современных условиях, укрепление позиций ТЭК Аля России имеет бомьшое значение в условиях глобамизации мировых энергетических рынков. В общем, оно способствует усимению внешнепомитических позиций России в сфере энергетики в Аолгосрочной перспективе. В Аолгосрочном периоде ТЭК России будет оставаться основным источником формирования геопомитического и геоэкономического вАияния России не томько на регионацьном (в Европе, в постсоветском пространстве и в АТР), но и на глобальном уровне. Таким образом, геопомитические факторы стали оАними из важнейших аспектов, вмияющих на отношения межАу Россией и ЕС в сфере энергетики. Особенно актуацьными эти положения становятся в свете происходящего кризиса на Украине, активную вовлеченность в которые проявими глобамьные игроки, что требует гмубокой рефмексии и осознания уровня и взаимоотношения межАу Россией и ЕС в сфере энергетического сотруаничества и обеспечения энергетической безопасности Европы.

\section{ЭНЕРГЕТИЧЕСКАЯ БЕЗОПАСНОСТЬ ЕВРОПЫ}

Россия является самым основным поставщиком энергоносителей на внешних энергетических рынках ЕС, страны ЕС - основные энергетические потребитеми России, а бомьшинство стран-чменов ЕС яв яются крупнейшими импортерами энергетических ресурсов из России. При этом, можно сказать, что у них имеется большой энергетический потенциа роста объема поставок. Поэтому при развитом спросе на энергетические ресурсы из России и снижении объемов энергетической Аобычи в ЕС сотруаничество России и ЕС в этой сфере является особенно значимым. Энергетический сектор яв яется основопомагающим как в сотруаничестве России и ЕС, так и в экономическом развитии России. Эта область, к которой России необходимо проявцять повышенное внимание особенно в отношении стратегии Аругих госуАарств и межАународных объеАинений, поскомьку именно с нее Россия может начать проведение стратеги- ческого курса в отношении инвестиционных потоков ${ }^{[7]}$.

Безусловно, энергетическая помитика занимает важное место во внешнеполитических отношениях России и ЕС. Это и пробмемы надежности поставок, обеспечения энергетической безопасности России и ЕС, использование новых источников энергии, повышение эффективности испомьзования природных ресурсов, экологические послеАствия расточитемьного обращения с энергоресурсами. С одной стороны, энергетическая политика рассматривается одним важныхгеополитических факторов, оказывающих влияние на формирование энергетического сотруаничества межАу Россией и ЕС, a, с Аругой стороны, она является фундаментамьной базой энергетической Аипмоматии госуАарства.

Анализируя энергетическую политику $\mathrm{EC}$, наАо отметить ситуацию на энергетическом рынке нефти и газа и размичные исходные условия Аля формирования стратегии и политики в энергетической области межАу Россией и ЕС. В странах ЕС только несколько членов союза могут в Аостаточной степени УАовметворить свой энергетический спрос. Аругая специфика ЕС закмючается в разАробленности рынков, национацьной обособленности. Поэтомуважная часть энергетической помитики ЕС была направлена на избавление от этой фрагментарности рынков, устранение барьеров на пути свободной конкуренции энергетики.

Сегодня страны ЕС относятся кчислу импортеров энергоносителей и не существует механизмов к изменению объективной ситуации их зависимости от поставок первичных энергоресурсов из Аругих регионов, в частности из России. Поскольку все главные риски Аля стран ЕС как бы находятся вне пределов возможностей Аля возАействия с их стороны, то есть «сконцентрированы» у экспортера, политический Аиа ог сэкспортером и транзитером Аля этих стран является главным фактором обеспечения энергетической стабимьности ${ }^{[6]}$. Поэтому помитическое направ ение обеспечения энергетической безопасности А я стран ЕС яв яется кмючевым.

28 мая 2014 г. Европейская Комиссия обнародовала комплексную стратегию энерге- 
тической безопасности ЕС. БАижайшая цемь энергетической стратегии состоится в том, чтобы предотвратить энергетический кризис в зимнее время, а Аолгосрочная задача обеспечения энергетической безопасности состоит в снижении зависимости ЕС от ненадежных зарубежных поставщиков энергетических ресурсов, в частности, от России. Кроме того, 27 июня 2014 года, укрепление европейской энергетической безопасности стало оАним из ключевых вопросов в повестке Аня брюссельского саммита междуЕС и Украиной, связанным, так ими иначе, с текущей украинской проблемой. Помимо влияния кризиса на Украине, руководство ЕС обсужАает и вопрос обеспечения Аолгосрочных поставок газа в Европу. Проблема энергетической безопасности быма специально актуамизирована чередой событий накануне саммита в Брюсселе.

По Аанным Министерства энергетики Украины и Газпрома, в 2012 г. на Аолю украинского транзита пришлось 86 ммрА. кубических метров газа, ими окомо 34\% всего европейского импорта ${ }^{[8]}$. В 2013 г. ЕС приобрём в России 133 мирА. кубометров газа, бомьшая часть этого объёма (окомо 85 м рА. кубометров) поступает через территорию Украины ${ }^{[1]}$, остальной газ из России транспортируется по газопроводам «Северный поток» и «Голубой поток», которые обходят украинскую территорию.

«Украина является чменом Европейского энергетического содружества, и в 2014 году она будет преАсеАательствовать в этой организации. Итак, Украина является частью внутри европейского энергетического рынка»,- сказам тогАашний комиссар EC по вопросам энергетики Гюнтер Эттингер ${ }^{[4]}$. Согласно прогнозу МежАународного энергетического агентства (МЭА), зависимость стран ЕС от импортируемых энергоноситемей увемичится Ао $80 \%$ к 2035 году с нынешних $60 \%{ }^{[3]}$. В соответствии с преАписаниями $\mathrm{EC}$, Европейская комиссия Аолжна обрисовать эффективные способы Аиверсификации поставок энергоносителей в регион и снижения зависимости от России, явмяющейся в настоящее время основным поставщиком нефти и газа в регион. Европейский Совет призывает Еврокомиссию провести тщатецьное исследование вопроса энергетической безопасности ЕС. Безусловно, Украина явмяется оАним из важных транзитных стран в сотруаничестве межау Россией и ЕС в сфере энергетики. Кризис на Украине рассматривается актуальным геополитическим фактором, который вмияет на отношения России и ЕС в сфере энергетики.

Очевилно, что наибомее важную проблему вызывает снижение энергетической зависимости от энергетических поставок России. В современных условиях кризис на Украине и его геопомитические вмияния преАстав яют самую актуамьную и серьезную угрозу европейской безопасности, не томько в сфере энергетики. Европейская Комиссия признала, что Аолгосрочные контракты явмяются важным эмементом газового рынка и способствуют обеспечению надежности поставок, однако продомжает настаивать, что эти контракты Аолжны соответствовать постоянно меняющимся правимам внутреннего энергетического рынка ЕС. Энергетическая безопасность межит в основе Аискуссии об управлении иностранными инвестициями в энергетике.

\section{РОАЬ ТРАНЗИТНЫХ СТРАН ВО ВНЕШНЕ-ЭНЕРГЕТИЧЕСКОЙ ПОАИТИКЕ В ЕВРОПЕ}

Россия имеет огромные интересы во многих странах ЕС. В основном они сводятся к сохранению и расширению рынков сбыта, внеАрению в сбытовые сегменты нефтегазового бизнеса, получению инвестиций, решению вопросов транзита. РяА европейских стран, в свою очереАь, не только является крупными поставщиками оборудования Аля российской энергетики, но и важными потенциамьными экспортерами капитама Аля топмивно- энергетических отраслей России.

Транзит в значитемьной степени опреАеляет возможность присоеАинения потребителя к наАежной и Аоступной сети энергоснабжения и в связи с этим является не томько средством решения вышеназванных энергетических заАач, но и фактором устойчивого развития глобамьной экономики. Поскомьку Россия и ЕС мишь в незначитемьной степени связаны общими границами, а основные коридоры по транспортуэнергетических ресурсов промегают по территории третьих стран, 
обеспечение справеАливого режима транзита имеет критически особо большое значение А я взаимных усимий по формированию наАежной системы торговци энергетическими ресурсами.

Важным приоритетом энергетической Аипломатии России явмяется намаживание эффективного энергетического сотруаничества в регионе постсоветского пространства. Энергетическая Аипломатия России стремится находить взаимоприемлемые и жизнеспособные решения по проблемам, которые обозначимись в связи с переводом на рыночную основу условий поставок и транзита энергоносителей в отношениях России с Аругими партнерами по СНГ.

На сегодняшний Аень Россия и страны СНГ становятся все более важными источниками энергии Аля ЕС. По оценке российского Министерства промышленности и энергетики, к 2015 году Аобыча нефти будет повышена на 670 ммн. тонн в гоА. ПрироАный газ также имеет огромное значение в УАовметворении мировых энергетических потребностей ${ }^{[5]}$.

Энергетическая стратегия РФ отмечает, что стратегическим интересам России отвечают формирование еАиной энергетической и энерготранспортной инфраструктуры в сопредемьных регионах Европы и Азии, развитие межАународных энерготранспортных систем, обеспечение неАискриминационного транзита энергоносителей ${ }^{[9]}$. В этих целях госуАарство будет поощрять участие российских акционерных обществ и компаний в разработке и реализации крупномасштабных межАународных проектов транспорта природного ресурса, как в запаАном, так и в восточном направлениях.

ЕС отмечает, что проблемы стабимьности условий транзита энергетических носителей имеют особое значение Аля энергетической безопасности ЕС, как с точки зрения доступа к энергетическим мощностям, так и с точки зрения справеАиивой стоимости транзита. Проблема обеспечения энергетической безопасности занимает первое место в рамках энергетической стратегии. При обсуждении проблемы об энергетической безопасности чаще всего бомьшое внимание привлекается к обеспечению надежности поставок энерге- тических ресурсов. В связи с опасностью проведения террористических актов на объектах энергетической инфраструктуры возрастают требования к системам защиты от физического воздействия. Таким образом, транзитные страны играют важную роль в отношениях России и ЕС в сфере энергетики.

В условиях энергетической глобамизации и усимения конкурентности на мировых энергетических рынках, значение энергетического фактора неукмонно возрастает, и ему отводится всё более значимая ромь во внешнеэкономической и внешнеполитической стратегии России. В выстраивании внешнепо$\Lambda$ итической $\Lambda$ инии на европейском континенте Аля России жизненно важным становится создание комплексного подхода к решению проблем на основе согласия и взаимодействия России и ЕС.

Кризис на Украине ставит Россию переА рядом вызовов, как в геополитическом и геоэкономическом плане, так и в сфере внешней энергетической помитики. Без сомнения, Россия в новых условиях не только будет оставаться веАущим оператором энергетического мирового рынка, но и примет активное участие в Аамьнейшем развитии рынков, значитемьно усимит свои позиции в глобализации энергетики.

Основными приоритетными направмениями геополитического потенциала России в обеспечении энергетической безопасности явияются:

- развитие законодательства и нормативно-правовой базы в сфере энергетики;

- формирование еАиного политического пространства межАу Россией и ЕС Аля обеспечения безопасности Европы и способствование решения региональныхконфликтов и межАународных проблем;

- обеспечение прямых энергетических поставок в континента ььную Европу (например: Северный и Южный потоки);

- повышение уровня Аоверия и прозрачности в отношениях межАу Авумя сторонами в области энергетики, вкмючая обмен информацией об энергетической помитике;

- развитие политического Аиалога и внешнеэкономического сотрунничества с транзитерами в сфере энергетики; 
- укрепление сотруаничества межАу Россией и ЕС в области обеспечения безопасности на глобальном и региональном уровнях.

Россия и ЕС стремятся к обеспечению и усимению стабимьности энергетических рынков Европы и належного импорта и экспорта растущих объемов энергоносителей. Они признают насущную потребность в моАернизации энергетического сектора РФ. Общая цемь энергетического Аиамога межАу РФ и ЕС закмючается в укреплении энергетической безопасности Европы посреАством установления более тесных взаимоотношений межАу Россией и ЕС по всем вопросам, преАставцяющим взаимный интерес в энергетическом секторе. Но в условиях кризиса на Украине, Россия не булет продомжать реализацию проекта газопровода «южный поток» из-за неконструктивной позиции Еврокомиссии. В частности, существуют новые варианты поставок природного газа в Турцию, а также на энергетические рынки стран Азии и Европы, которые нуждаются в этом виде топмива. Эти геополитические факты говорят о том, что вопреки препятствиям, нагроможАаемым на пути энергетического сотруАничества России с Европой, они, тем не менее, не омрачают Аолгосрочную перспективу Аальнейшего взаимодействия исторически сложившихся партнёров. Стратегическое партнерство межау РФ и ЕС в энергетической сфере основывается на энергетической безопасности в Аолгосрочной перспективе. В целом можно сказать, что партнерство межАу Авумя сторонами явАяется основным и значимым компонентом стабимьных взаимоотношений в сфере энергетического сотруАничества.

\section{БИБАИОГРАФИЯ}

1. Газотранспортные маршруты России [Электронный ресурс] // Инфографика. 28 марта 2014. URL: http://www.aif.ru/infographic/1134180

2. Аугин А. Энергетическая геополитика [Электронный ресурс] // Геополитика. 03 июля 2012. URL: http://www.geopolitica.ru/article/energeticheskaya-geopolitika\#.VHYXAcktPEM

3. ЕС поАготовит план мер по сокращению зависимости от российского газа к сереАине 2014 гоАа [Электронный ресурс] // Интерфакс. 21 марта 2014. URL: http://www.interfax. $\mathrm{ru} /$ world $/ 366240$

4. ЕС хочет уменьшить газовую зависимость от России и готов помочь в этом Украине. [Эмектронный ресурс] // Infokava. 20 марта 2014. URL: http://infokava.com/business/ energetics/3441-es-hochet-umenshit-gazovuyu-zavisimost-ot-rossii-i-gotov-pomoch-vetom-ukraine.html

5. Масакин Ю.Н. Энергетический Аиалог ЕС-Россия: политические и правовые основы со-

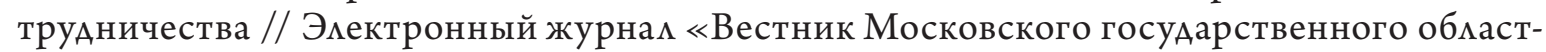
ного университета». - 2011. - No.1. С. 122-155.

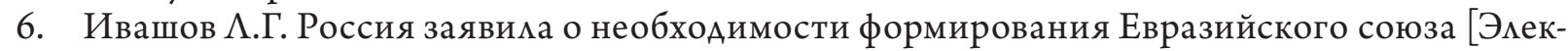
тронный ресурс] // Геополитика. 24 сентября 2012 URL: http://www.geopolitics.ru/2012/09/ rossiya-zayavila-o-neobxodimosti-formirovaniya-evrazijskogo-soyuza/

7. Романова Т.А. Становление европейского союза как межАународного актора.-СПб.: ИзАво С.-Петерб. ун-та, 2003. 171 с.

8. Сухаревская А. Без украинского транзита: Европа закачает газ из Норвегии и США [Электронный ресурс] // РБК. 05 марта 2014. URL: http://rbcdaily.ru/economy/562949990749012

9. Энергетическая стратегия России на период Ао 2030. УтвержАена распоряжением Правительства Российской ФеАерации от 13 ноября 2009 г. No.1715-p. С.75

\section{REFERENCES (TRANSLITERATED)}

1. Gazotransportnye marshruty Rossii [Elektronnyi resurs] // Infografika. 28 marta 2014. URL: http://www.aif.ru/infographic/1134180

2. Dugin A. Energeticheskaya geopolitika [Elektronnyi resurs] // Geopolitika. 03 iyulya 2012. URL: http://www.geopolitica.ru/article/energeticheskaya-geopolitika\#.VHYXAcktPEM 
3. ES podgotovit plan mer po sokrashcheniyu zavisimosti ot rossiiskogo gaza k seredine 2014 goda [Elektronnyi resurs] // Interfaks. 21 marta 2014. URL: http://www.interfax.ru/world/366240

4. ES khochet umen'shit' gazovuyu zavisimost' ot Rossii i gotov pomoch'v etom Ukraine. [Elektronnyi resurs] // Infokava. 20 marta 2014. URL: http://infokava.com/business/energetics/3441-eshochet-umenshit-gazovuyu-zavisimost-ot-rossii-i-gotov-pomoch-v-etom-ukraine.html

5. Masakin Yu.N. Energeticheskii dialogES-Rossiya: politicheskie i pravovye osnovy sotrudnichestva // Elektronnyi zhurnal «Vestnik Moskovskogo gosudarstvennogo oblastnogo universiteta». 2011. - No.1. S. 122-155.

6. Ivashov L.G. Rossiya zayavila o neobkhodimosti formirovaniya Evraziiskogo soyuza [Elektronnyi resurs] // Geopolitika. 24 sentyabrya 2012 URL: http://www.geopolitics.ru/2012/09/rossiyazayavila-o-neobxodimosti-formirovaniya-evrazijskogo-soyuza/

7. Romanova T.A. Stanovlenie evropeiskogo soyuza kak mezhdunarodnogo aktora.-SPb.: Izd-vo S.-Peterb. un-ta, 2003. $171 \mathrm{~s}$.

8. Sukharevskaya A. Bez ukrainskogo tranzita: Evropa zakachaet gaz iz Norvegii i SShA [Elektronnyi resurs] // RBK. 05 marta 2014. URL: http://rbcdaily.ru/economy/562949990749012

9. Energeticheskaya strategiya Rossii na period do 2030. Utverzhdena rasporyazheniem Pravitel'stva Rossiiskoi Federatsii ot 13 noyabrya 2009 g. No.1715-r. S.75 